\title{
MENINGKATKAN HASIL BELAJAR SISWA MELALUI MODEL PEMBELAJARAN KONTEKSTUAL DI KELAS V SDN 1 WALASIHO
}

\author{
Hastuti $^{1)}$, Muhammad Yasin ${ }^{2)}$ \\ 1) SDN 1 Walasiho, Kolaka Utara, Indonesia \\ ${ }^{2)}$ Jurusan PGSD, Universitas Halu Oleo, Kendari, Indonesia \\ email: hastutikolut@gmail.com
}

\begin{abstract}
Abstrak: Tujuan penelitian ini untuk meningkatkan hasil belajar siswa khususnya materi Penyesuaian diri makhluk hidup dan lingkungannya di Kelas V SD Negeri 1 Walasiho melalui model pembelajaran Kontekstual. Prosedur penelitian mengikuti prosedur penelitian tindakan kelas yaitu; (a) perencanaan, (b) pelaksanaan tindakan, (c) observasi dan evaluasi, dan (d) refleksi. Hasil menunjukkan bahwa hasil belajar siswa dengan ratarata pada siklus I adalah 63,85 dan siswa yang mencapai ketuntasan belajar sebesar $61,54 \%$. Pada siklus II, rata-rata hasil belajar siswa meningkat menjadi 74,62 dan siswa yang mencapai ketuntasan belajar mencapai $84,62 \%$. Keberhasilan aktivitas mengajar guru dihitung berdasarkan skor perolehan guru dibagi dengan skor maksimum dikalikan seratus persen sehingga persentase keberhasilan aktivitas mengajar guru siklus I pertemuan pertama adalah $76,92 \%$ dan pertemuan kedua $84,62 \%$. pada siklus II pertemuan pertama adalah $84,62 \%$ dan pertemuan kedua adalah $100 \%$. Keberhasilan aktivitas belajar siswa dihitung berdasarkan skor perolehan siswa dibagi dengan skor maksimum dikalikan seratus persen, sehingga persentase keberhasilan aktivitas belajar siswa siklus I pertemuan pertama adalah $76,92 \%$ dan pertemuan kedua $84,62 \%$.pada siklus II pertemuan pertama adalah $84,62 \%$ dan pertemuan kedua adalah $100 \%$.
\end{abstract}

Kata Kunci: pembelajaran kontekstual; hasil belajar

\section{IMPROVING THE STUDENT'S LEARNING OUTCOMES THROUGH CONTEXTUAL LEARNING MODELS IN CLASS V SDN 1 WALASIHO}

\begin{abstract}
This research aimed to improve students' learning outcomes, especially the material adjustment of living things and their environment in Class V SD Negeri 1 Walasiho through the Contextual learning model. The research procedure followed the classroom action research procedure, namely; (a) planning, (b) implementing actions, (c) observation and evaluation, and (d) reflection. The results showed that student learning outcomes in the material adjustment of living things and their environment in Class V SD Negeri 1 Walasiho with an average in the first cycle was 63.85 and students who achieved learning completeness were $61.54 \%$. In cycle II, the average student learning outcomes increased to 74.62 and students who achieved mastery learning reached $84.62 \%$. The success of teacher teaching activities is calculated based on the score obtained by the teacher divided by the maximum score multiplied by one hundred percent so that the percentage of successful teaching activities of teachers in the first cycle of the first meeting is $76.92 \%$ and the second meeting is $84.62 \%$. in the second cycle the first meeting was $84.62 \%$ and the second meeting was 100\%. The success of student learning activities is calculated based on the student acquisition score divided by the maximum score multiplied by one hundred percent, so the percentage of success in student learning activities in the first cycle of the first meeting was $76.92 \%$ and the second meeting was $84.62 \%$. In the second cycle the first meeting was $84.62 \%$ and the second meeting is $100 \%$.
\end{abstract}

Keywords: contextual learning; learning outcomes 


\section{Pendahuluan}

Pendidikan bertujuan untuk mengembangkan sumber daya manuasia yang dilakukan secara sistematis, praktis, dan berjenjang. Untuk mewujudkan tujuan tersebut guru memiliki peranan penting demi tercapainya proses belajar yang baik. Sehubungan dengan peranan ini, seorang guru dituntut harus mempunyai kompetensi yang memadai dalam hal pengajaran di sekolah. Kurangnya kompetensi guru akan menyebabkan pelaksanaan mengajar menjadi kurang lancar yang berimplikasi pada siswa, sehingga siswa dapat mengalami berbagai kesulitan belajar dan hasil belajarnya menurun. Selama ini pembelajaran IPA di sekolah, khususnya SD Negeri 1 Walasiho masih menggunakan sistem konvensional, dimana pembelajaran yang berlangsung masih didominasi metode ceramah dan pemberian tugas (pembelajaran mekanistik) sehinga siswa kurang melibatkan dalam proses pembelajaran.

Pendidikan IPA sebagai salah satu cabang ilmu pengetahuan yang memberikan kontribusi positif dalam memacu ilmu pengetahuan dan teknologi sehingga menjadi sangat penting dalam upaya peningkatan mutu ilmu pengetahuan dan teknologi meningkatkan rasa keimanan dan ketaqwaan.

Gambaran proses belajar IPA yang dikemukakan di atas juga merupakan fenomena yang terjadi di SD Negeri 1 Walasiho. Berdasarkan pengalaman selama mengajar di sekolah tersebut bahwa hasil belajar siswa kelas V masih rendah. Dari data hasil belajar siswa kelas V SD Negeri 1 Walasiho semester ganjil tahun pelajaran 2015/2016 menujukkan hasil belajar siswa yang tuntas mencapai 52,38\%. Hasil belajar ini masih berada dibawah standar Kriteria Ketuntasan Minimal (KKM) yang ditetapkan di sekolah yakni minimal $80 \%$ siswa memperoleh nilai $\geq 65$.

Sesuai dengan faktor kebutuhan individual siswa, maka untuk dapat mengimplementasikan pembelajaran dan pengajaran kontekstual. Anak belajar dengan cara berinteraksi dengan lingkungan. Pengetahuan dibentuk sendiri oleh individu dan pengalaman merupakan kunci utama dari belajar bermakna. Melalui keterlibatan secara aktif, anak secara terus-menerus mendapatkan pengalaman belajar. Belajar yang bermakna tidak akan terwujud hanya dengan mendengarkan ceramah atau membaca buku tentang pengalaman orang lain yang sudah diabrasikan. Menurut Mulyana dan Nana dalam Patimasang (2014, p.135) belajar merupakan perubahan perilaku sebagai fungsi pengalaman, yang mencakup perubahan-perubahan afektif, psikomotorik, dan kognitif, yang tidak dihasilkan oleh sebab-sebab lain. Menurut Ulfah (2016, p.1610) mengemukakan bahwa hasil belajar merupakan hasil keberhasilan dari interaksi belajar mengajar yang mencakup bidang kognitif, afektif, dan psikomotorik yang ditunjukkan dengan perubahan tingkah laku yang khas. Menurut Hamalik dalam Nupiksani (2015, p.15) bahwa hasil belajar menunjukkan kepada prestasi belajar, sedangkan prestasi belajar itu merupakan indikator adanya derajat perubahan tingkah laku siswa. Senada dengan Rosidah (2017, p.30) menjelaskan bahwa hasil belajar siswa adalah perolehan hasil yang dicapai siswa dalam usaha belajarnya sebagaimana dicantumkan dalam nilai rapornya. Melalui hasil belajar seorang siswa dapat mengetahui kemajuankemajuan yang telah dicapainya dalam belajar. Seorang siswa dikatakan telah mencapai perkembangannya secara optimal apabila siswa dapat memperoleh pendidikannya dan hasil belajar yang sesuai dengan bakat, kemampuan dan minat yang dimilikinya.

Untuk itu perlu dicari pemecahan masalahnya dalam menentukan strategi pembelajaran yang tepat, dengan tetap mempertimbangkan kondisi-kondisi dalam kelas. Semuanya dimaksudkan untuk memperoleh model pembelajaran yang tepat bagi seluruh siswa. Oleh karena itu, penulis menganggap perlu untuk melakukan penelitian tindakan kelas untuk memperbaiki proses pembelajaran. Salah satu model pembelajaran yang digunakan adalah dengan pendekatan kontekstual. 
Model pembelajaran dengan Model pembelajaran Kontekstual merupakan pembelajaran yang melibatkan siswa secara aktif dalam proses pembelajaran serta siswa didorong untuk berusaha menemukan sendiri apa yang seharusnya dipelajari. Upaya untuk mencapai tujuan tersebut guru dapat menerapkan model pembelajaran Contextual Teaching and Learning (CTL). Elaine B. Johnson dalam Khotimah (2013, p.2) menyatakan bahwa "CTL adalah sebuah sistem belajar yang didasarkan pada filosofi bahwa siswa mampu menyerap pelajaran apabila mereka menangkap makna dalam materi akademis yang mereka terima, dan mereka menangkap makna dalam tugas-tugas sekolah jika mereka bisa mengaitkan informasi baru dengan pengetahuan dan pengalaman yang sudah mereka miliki sebelumnya." Model pembelajaran Contextual Teaching and Learning (CTL) dapat membantu dalam meningkatkan keterampilan sosial siswa. Nurhadi, dkk. (2004, p.13) menjelaskan bahwa CTL merupakan suatu konsep belajar dimana guru menghadirkan situasi dunia nyata ke dalam kelas dan mendorong siswa membuat hubungan antara pengetahuan yang dimilikinya dengan penerapannya dalam kehidupan mereka sebagai anggota keluarga dan masyarakat. Proses pelaksanaan pembelajaran akan berlangsung lebih alamiah dalam bentuk kegiatan siswa bekerja dan mengalami, bukan transfer pengetahuan dari guru. Menurut Johnson dalam Kurniawan (2015, p.173) CTL merupakan model pembelajaran yang diyakini dapat meningkatkan aktivitas belajar siswa. Model pembelajaran ini berasumsi bahwa dalam kegiatan pembelajaran guru harus mengkaitkan antara materi yang diajarkan dengan situasi dunia nyata serta mendorong siswa membuat hubungan antara pengetahuan yang dimilikinya dengan penerapan dalam kehidupan mereka sebagai anggota keluarga dan masyarakat."

Berdasarkan kenyataan tersebut di atas maka perlu dilakukan suatu upaya untuk meningkatkan hasil belajar siswa di sekolah dasar khususnya dalam pembelajaran IPA. Salah satu alternatif yang dapat dilakukan adalah penggunaan metode belajar yang tepat dalam menyajikan materi kepada siswa. Upaya tersebut adalah dengan menerapkan metode pembelajaran yang tepat. Untuk itu penulis menerapkan Model pembelajaran Kontekstual khususnya dalam pembelajaran IPA di SD Negeri 1 Walasiho.

Atas dasar pertimbangan yang mengarah pada peningkatan hasil belajar siswa, maka peneliti mencoba melakukan penelitian dalam bentuk penelitian tindakan kelas dengan judul: "Meningkatkan Hasil Belajar siswa pada materi pokok penyesuai diri makhluk hidup dan lingkungan Melalui Model pembelajaran Kontekstual di Kelas V SD Negeri 1 Walasiho Kolaka Utara".

Masalah dalam penelitian ini adalah: Apakah hasil belajar siswa pada materi Penyesuaian diri makhluk hidup dan lingkungannya dapat ditingkatkan dengan menggunakan model pembelajaran Kontekstual di Kelas V SD Negeri 1 Walasiho Kab. Kolaka Utara? Tujuan penelitian ini adalah untuk meningkatkan hasil belajar siswa khususnya materi Penyesuaian diri makhluk hidup dan lingkungannya di kelas V SD Negeri 1 Walasiho melalui model pembelajaran Kontekstual. Penelitian ini diharapkan dapat memberikan manfaat bagi guru, siswa, sekolah dan penelitian lainnya.

\section{Metode}

Jenis penelitian adalah penelitian tindakan kelas (PTK. dilaksanakan pada kelas V semester Ganjil Tahun Pelajaran 2016/2017 pada SD Negeri 1 Walasiho Kabupaten Kolaka Utara dengan subyek dalam penelitian ini adalah siswa Kelas V SD Negeri 1 Walasiho Kabupaten Kolaka Utara semester I Tahun Pelajaran 2016/2017 dengan jumlah siswa 13 orang. Penelitian tindakan kelas ini dilaksanakan dalam dua siklus yang terdiri dari empat tahapan yaitu perencanaan, pelaksanaan tindakan, observasi dan evaluasi serta refleksi Jenis data dalam penelitian ini adalah data kualitatif dan kuantitatif. Data kualitatif berupa kegiatan 
proses pembelajaran aktivitas belajar siswa dan aktivitas guru. Data kuantitatif berupa nilai hasil belajar siswa. Sumber data dalam penelitian ini adalah guru dan siswa Kelas V SD Negeri 1 Walasiho Kabupaten Kolaka Utara.

Data kualitatif akan dianalisis secara deskriptif kualitatif berdasarkan observasi, sedangkan data kuantitatif dianalisis secara kuantitatif menggunakan rumus: Indikator keberhasilan dalam penelitian ini adalah 1) Hasil belajar siswa dikatakan berhasil apabila 80 $\%$ siswa mencapai nilai 65 sesuai KKM yang ditetapkan sekolah 2) Ketuntasan aktifitas mengajar guru dianggap berhasil apabila dalam pelaksanaan skenario pembelajarn mencapai minimal $80 \%$ dari keseluruhan skenario pembelajaran. 3) Ketuntasan aktifitas belajar siswa dikatakan berhasil apabila dalam kegiatan siswa dalam proses pembelajaran mencapai $80 \%$ dari keseluruhan kegiatan siswa dalam proses pembelajaran.

\section{Hasil}

\section{Hasil Belajar Siswa}

Pada pembelajaran siklus I, siswa yang memperoleh nilai $<65$ berjumlah 5 orang $(38,46 \%)$, siswa yang memperoleh nilai $\geq 65$ berjumlah 8 orang $(61,54 \%)$. Berdasarkan nilai siswa pada tabel 4.3, ketuntasan belajar siswa mencapai 61,54\%, dimana siswa yang memperoleh nilai $\geq 65$ berjumlah 8 orang sedangkan siswa yang belum mencapai ketuntasan belajar berjumlah 5 orang. pada pembelajaran siklus II, siswa yang memperoleh nilai rentang 0-64 berjumlah 2 orang $(15,38 \%)$ dan siswa yang memperoleh nilai rentang 65-100 berjumlah 11 orang $(84,62 \%)$. Evaluasi pada siklus II menunjukkan bahwa ketuntasan belajar siswa sebesar $84,62 \%$ dan telah mencapai indikator keberhasilan penelitian maka pelaksanaan tindakan dihentikan pada siklus II.

\section{Aktivitas Guru}

Skor perolehan guru pada siklus I pertemuan pertama adalah 10 dan pertemuan kedua adalah 11. Keberhasilan aktivitas mengajar guru dihitung berdasarkan skor perolehan guru dibagi dengan skor maksimum dikalikan seratus persen sehingga persentase keberhasilan aktivitas mengajar guru siklus I pertemuan pertama adalah $76,92 \%$ dan pertemuan kedua $84,62 \%$. bahwa skor perolehan guru pada siklus II adalah pertemuan pertama adalah 12 dan pertemuan kedua adalah 13 maka keberhasilan aktivitas mengajar guru pada siklus II pertemuan pertama adalah $84,62 \%$ dan pertemuan kedua adalah $100 \%$.

\section{Aktivitas Siswa}

Skor perolehan siswa pada siklus I pertemuan pertama adalah 10 dan pertemuan kedua adalah 11. Keberhasilan aktivitas belajar siswa dihitung berdasarkan skor perolehan siswa dibagi dengan skor maksimum dikalikan seratus persen, sehingga persentase keberhasilan aktivitas belajar siswa siklus I pertemuan pertama adalah $76,92 \%$ dan pertemuan kedua $84,62 \%$. skor perolehan siswa pada siklus II pertemuan pertama adalah 12 dan pertemuan kedua adalah 13 maka keberhasilan aktivitas belajar siswa pada siklus II pertemuan pertama adalah $84,62 \%$ dan pertemuan kedua adalah $100 \%$.

\section{Pembahasan}

Sebelum melaksanakan penelitian, dilakukan kegiatan pendahuluan berupa pengamatan hasil belajar siswa. Pengamatan dilakukan dengan maksud untuk mengetahui tingkat pemahaman siswa dan kelemahan-kelemahan dalam proses pembelajaran khususnya model pembelajaran yang diterapkan pada pembelajaran sebelumnya.

Hasil pengamatan menunjukkan bahwa dari 13 siswa Kelas V SD Negeri 1 Walasiho ketuntasan belajar siswa sebesar 52,38\% yang memperoleh skor $\geq .65$ Hasil tersebut 
membuktikan bahwa pemahaman siswa terhadap materi penyesuaian diri makhluk hidup dan lingkungannyapada Kelas V SD Negeri 1 Walasiho masih rendah. Hasil pengamatan tersebut dijadikan dasar dalam melakukan perbaikan pembelajaran untuk meningkatkan hasil belajar siswa Kelas V SD Negeri 1 Walasiho materi penyesuaian diri makhluk hidup dan lingkungannya.

Setelah didiskusikan dengan guru kolaborator, diputuskan untuk menggunakan model pembelajaran kontekstual dalam rangka meningkatkan hasil belajar siswa Kelas V SD Negeri 1 Walasiho. Pada setiap siklus, peneliti melaksanakan pembelajaran berdasarkan RPP yang telah disiapkan dengan model pembelajaran kontekstual. Pada saat pembelajaran sedang berlangsung, peneliti diamati oleh teman sejawat yang bertindak sebagai observer. Berdasarkan hasil observasi pada siklus I, guru dan siswa telah melakukan kegiatan pembelajaran yang sesuai dengan pendekatan kontekstual. Namun, masih terdapat kekurangan yang dilakukan guru dan masalah yang dihadapi siswa dalam proses pembelajaran. Kekurangan yang dilakukan guru dalam proses pembelajaran adalah guru melaksanakan proses pembelajaran tidak secara sistematis dan tidak sesuai pendekatan kontekstual. Kekurangan tersebut berdampak pada rendahnya skor perolehan guru. Skor perolehan guru pada siklus I pertemuan pertama adalah 10 dan pertemuan kedua adalah 11 . Keberhasilan aktivitas mengajar guru dihitung berdasarkan skor perolehan guru dibagi dengan skor maksimum dikalikan seratus persen sehingga persentase keberhasilan aktivitas mengajar guru siklus I pertemuan pertama adalah $76,92 \%$ dan pertemuan kedua $84,62 \%$.

Kekurangan yang dilakukan guru dalam pembelajaran berdampak pada proses belajar siswa, sehingga ada masalah yang dialami siswa. Masalah yang dialami siswa dalam proses pembelajaran adalah siswa belum memahami materi pelajaran dengan baik yang berpengaruh pada skor perolehan siswa. Skor perolehan siswa pada pembelajaran siklus I pertemuan pertama adalah 10 dan pertemuan kedua adalah 11. Keberhasilan aktivitas belajar siswa dihitung berdasarkan skor perolehan siswa dibagi dengan skor maksimum dikalikan seratus persen, sehingga persentase keberhasilan aktivitas belajar siswa siklus I pertemuan pertama adalah 76,92\% dan pertemuan kedua 84,62\%.

Melihat kekurangan yang masih ada serta hasil belajar siswa belum mencapai indikator keberhasilan yang telah ditetapkan, maka penelitian dilanjutkan pada tindakan siklus II. Hal-hal yang harus diperbaiki pada tindakan siklus II adalah guru lebih mengaktifkan siswa dan menunjuk siswa untuk menanyakan materi yang belum dipahami. Guru mengelola tahapan kegiatan pembelajaran dengan baik berdasarkan skenario pembelajaran dengan pendekatan kontekstual. Proses pembelajaran yang baik berpengaruh peningkatan skor perolehan guru dan siswa. Skor perolehan guru pada siklus II pertemuan pertama adalah 12 dan pertemuan kedua adalah 13 maka keberhasilan aktivitas mengajar guru pada siklus II pertemuan pertama adalah $92,31 \%$ dan pertemuan kedua adalah $100 \%$ sedangkan skor perolehan siswa pada siklus II pertemuan pertama adalah 12 dan pertemuan kedua adalah 13 maka keberhasilan aktivitas belajar siswa pada siklus II pertemuan pertama adalah $92,31 \%$ dan pertemuan kedua adalah $100 \%$.

Kualitas pembelajaran siklus I dan siklus menunjukkan peningkatan. Jika pada siklus I, banyak masalah yang dihadapi guru dan siswa maka pada siklus II permasalah itu sudah teratasi. Kualitas pembelajaran yang baik berdampak pada ketuntasan belajar siswa. Ketuntasan belajar siswa diketahui melalui analisis nilai siswa siklus I dan siklus II. Pada siklus I, rata-rata nilai siswa adalah 63,85 dan siswa yang mencapai ketuntasan belajar sebesar $61,54 \%$. Pada siklus II, rata-rata hasil belajar siswa meningkat menjadi 74,62 dan siswa yang mencapai ketuntasan belajar mencapai 84,62\%.

Evaluasi pada tindakan siklus II menunjukkan bahwa ketuntasan belajar siswa telah mencapai indikator yang telah ditetapkan. Sedangkan hasil observasi terhadap pelaksanaan 
pembelajaran bisa dikatakan sempurna, yakni seluruh komponen dalam skenario pembelajaran telah dilaksanakan dengan baik sesuai yang diharapkan. Karena belajar siswa telah tuntas dan komponen dalam skenario pembelajaran telah dilaksanakan maka hipotesis tindakan telah tercapai yakni penerapan pembelajaran kontekstual dapat meningkatkan hasil belajar IPA materi penyesuaian makhluk hidup dan lingkungannya pada siswa Kelas V SD Negeri 1 Walasiho.

Pembelajaran kontekstual adalah strategi pembelajaran yang menekankan kepada proses keterlibatan siswa secara penuh untuk dapat menemukan materi yang dipelajari dan menghubungkannya dengan situasi kehidupan nyata sehingga mendorong siswa untuk dapat menerapkannya dalam kehidupan mereka (Sanjaya,2007:253). Pendekatan kontekstual mendorong peran aktif siswa dalam pembelajaran, sehingga siswa dapat belajar efektif dan bermakna.Suatu proses belajar mengajar dikatakan bermakna jika siswa dapat mengaitkan pelajaran yang didapatnya dengan kehidupan nyata yang mereka alami. Pembelajaran dan pengajaran kontekstual sebagai sebuah sistem mengajar didasarkan pada pikiran bahwa makna muncul dari hubungan antara isi dan konteksnya. Konteks memberikan makna pada isi. Semakin banyak keterkaitan yang ditemukan siswa dalam suatu konteks yang luas, semakin bermaknalah isinya bagi mereka. Pengorganisasian proses belajar mengajar dikelas dengan strategi pembelajaran yang tepat adalah salah satu hal yang harus benar-benar dipahami oleh guru selaku pendidik untuk meningkatkan aktivitas sekaligus hasil belajar siswa (Untari, 2013, p.79).

Guru melaksanakan sejauh mungkin kegiatan kontekstual untuk semua hal yang berkaitan dengan materi pembelajaran melalui bahan bacaan, dan hal lain yang ada hubungannya dengan materi pelajaran. Dari hasil pengamatan siswa, guru mengembangkan sifat ingin tahu siswa dengan bertanya kepada anggota kelompok siswa dan guru. Ismail \& Elias (2006, p.21) menjelaskan bahwa "In order to fully grasp the concept, learners must experience inquiry directly to gain a deep understanding of its characteristics." Hasil penelitian ini bila dikaitkan dengan teori masih relevan. Senada dengan hal tersebut, Sagala (2010, p.87) mengemukakan bahwa hasil belajar dipengaruhi oleh beberapa faktor baik intern maupun ekstern. Model pembelajaran $C T L$ termasuk faktor yang berasal dari luar diri siswa yang mempengaruhi hasil belajar IPA siswa, hal ini dapat dipahami, karena model Contextual Teaching and Learning (CTL) merupakan konsep belajar yang membantu guru mengaitkan antara materi yang diajarkannya dengan situasi dunia nyata siswa dan mendorong siswa membuat hubungan antara pengetahuan yang dimilikinya dengan penerapannya dalam kehidupan mereka sebagai anggota keluarga dan masyarakat. Menururt Sagala dalam Kalsum, dkk (2014, p.184) dalam implementasinya,belajar adalah kegiatan individu mempeloleh pengetahuan,perilaku dan keterampilan dengan cara mengolah bahan belajar.

\section{Simpulan}

Berdasarkan hasil penelitian dan pembahasan, disimpulkan bahwa penerapan pendekatan pembelajaran kontekstual dapat meningkatkan hasil belajar siswa materi penyesuaian makhluk hidup dan lingkungannya di Kelas V SD Negeri 1 Walasiho. Hal ini dapat dilihat dari peningkatan rata-rata hasil belajar dan persentase ketuntasan belajar siswa. Pada siklus I, rata-rata hasil belajar siswa adalah 63,85 dan siswa yang mencapai ketuntasan belajar sebesar $61,54 \%$. Pada siklus II, rata-rata hasil belajar siswa meningkat menjadi 74,62 dan siswa yang mencapai ketuntasan belajar mencapai 84,62\% 


\section{Referensi}

Ismail, Noriah \& Elias, S. (2006). Inquiry-Based Learning: An Innovative Teaching Method Article. English Language Journal (2006) Vol.2(1): 13-24. UPSI Malaysia. https://www.researchgate.net/publication/259632827

Kalsum. (2014). Meningkatkan Hasil Belajar Siswa Kelas III SDN Pembina Liang Pada Pokok Bahasa Luas Segitiga Melalui Pendekatan Kontekstual. Jurnal Kreatif Tadulako Online Vol. 2, No. 2, 182190.http://jurnal.untad.ac.id/jurnal/index.php/JKTO/article/download/2849/1940

Khotimah. (2013). Penerapan Model Pembelajaran Contextual Teaching and Learning (CTL) Untuk Meningkatkan Hasil Belajar Siswa Mata Pelajaran IPA Kelas I SD. Jurnal Penelitian Pendidikan Guru Sekolah Dasar, vol. 1, no. 2, 1-10. https://media.neliti.com/media/publications/251015-none-ce1edce3.pdf

Kurniawan, D.A. (2015). Upaya Meningkatkan Aktivitas Belajar Pendidikan Kewarganegaraan (PKn) Melalui Model Pembelajaran Contextual Teaching and Learning (CTL). Trihayu: Jurnal Pendidikan Ke-SD-an, Vol. 1, Nomor 3, 172-175. https://media.neliti.com/media/publications/259029-upaya-meningkatkan-aktivitasbelajar-pen-e6e40251.pdf

Nupiksani, Sri. 2015. Meningkatkan Hasil Belajar Ips Melalui Penerapan Model Pembelajaran Group Investigation Pada Siswa Kelas VI SDN Rejoagung 01 Kecamatan Semboro Kabupaten Jember. Pancaran, Vol. 4, No. 4, hal 13-24. https://jurnal.unej.ac.id/index.php/pancaran/article/download/2174/1768/

Nurhadi, Burhan,Yasin dan Senduk, G.A. (2004). Pembelajaran Contextual Teaching and Learning $(C T L)$ dan Penerapannya dalam KBK. Malang: Universitas Negeri Malang

Patimasang, (2014). Peningkatan Hasil belajar IPS dengan menggunakan Metode Kerja Kelompok pada Siswa Kelas IV SDN Silampayang. Jurnal Kreatif Tadulako Online Vol.2 No. 4. 132-150. https://media.neliti.com/media/publications/118659-IDpeningkatan-hasil-belajar-ips-dengan-men.pdf

Rosidah, Ani. 2017. Penerapan Model Pembelajaran Kooperatif Snowball Throwing Untuk Meningkatkan Hasil Belajar Siswa Pada Pembelajaran IPS. Jurnal Cakrawala $\begin{array}{lllll}\text { Pendas } & \text { Vol. } & 3 & \text { No.2. } & \text { 29-36. }\end{array}$ http://jurnal.unma.ac.id/index.php/CP/article/download/593/556

Ulfah, KR, Anang Santoso, \& Utaya, Sugeng. (2016). Jurnal Pendidikan: HUBUNGAN MOTIVASI DENGAN HASIL BELAJAR IPS. Teori, Penelitian, dan Pengembangan Volume: 1 Nomor: 8 Bulan Agustus Tahun 2016 Halaman: 16071611. http://journal.um.ac.id/index.php/jptpp/article/view/6678/2885 
Untari, Yusrina Anggraini. (2013). Peningkatan Hasil Belajar IPS Siswa Kelas V Melalui Metode Simulasi Improved Results of IPS Learning Student Class V through Simulation Method. PSIKOPEDAGOGIA Jumal Bimbingan dan Konseling. Vol. 2, No. http://journal.uad.ac.id/index.php/PSIKOPEDAGOGIA/article/view/2574/2792Usma $\underline{\mathrm{n}}$

Uzer dan Setiawati, Lilis. (1993). Upaya Optimalisasi Kegiatan Belajar Mengajar. Remaja Rosdakarya. Bandung. 